\title{
Lesson Study dengan Metode Discovery Learning dan Problem Based \\ Instruction
}

\author{
Kardiana Metha Rozhana ${ }^{1}$, Harnanik ${ }^{2}$ \\ PGSD Universitas Tribhuwana Tunggadewi \& SDN 2 Pringapus \\ e-mail: jr.kardiana@yahoo.com ${ }^{1}$
}

\begin{abstract}
Abstrak
Tujuan dari penelitian ini yaitu mengetahui penerapan Lesson Study dengan metode Discovery Learning dan Problem Based Intruction dalam meningkatkan aktivitas siswa dalam proses pembelajaran. Penelitian ini menggunakan metode deskriptif kualitatif yaitu laporan penelitian hasil riset berupa kutipan-kutipan data yang diperoleh selama observasi untuk memberikan gambaran penyajian laporan secara deskripsi. Hasil peneitian menunjukkan melalui metode Discovery Learning dan Problem Based Intruction proses pembelajaran mampu meningkatkan keaktifan siswa, merangsang siswa tidak malu dalam bertanya, menumbuhkan rasa ingin tahu, proses pembelajaran menyenangkan, dan guru model dapat memperbaiki cara mengajar melalui saran yang diberikan oleh tim observer lesson study.
\end{abstract}

Kata kunci: Lesson Study, Discovery Learning, Problem Based Intruction

\section{PENDAHULUAN}

Implementasi Kurikulum 2013 sudah dirasa oleh guru sekolah dasar di kota maupun di pelosok desa. Dalam pelaksanaannya masih terdapat kesulitan bagi guru yang belum memahami konsep tematik sehingga dalam menyusun perangkat pembelajaran (Silabus, RPP, dan Media) pembelajaran tematik kurang maksimal diterapkan di sekolah dasar. Hal ini, mempengaruhi proses pembelajaran, guru yang seharusnya merancang pembelajaran lebih efektif dan inovatif terkendala karena kurangnya pengetahuan dan pelatihan. Sehingga, dibutuhkan pembentukan tim lesson study bagi guru SD agar proses pembelajaran lebih optimal. Salah satu kesulitan dalam pembelajaran tematik yaitu guru diharapkan mampu mengaitkan satu muatan mata pelajaran dengan muatan lain. Dalam hal ini, dibutuhkan kecapakan dan kemampuan dalam merancang sebuah pembelajaran yang dituangkan dalam Rencana Pelaksanaan Pembelajaran (RPP).

Upaya agar guru dapat merancang kegiatan pembelajaran yang efektif dan inovatif, maka diperlukan tim lesson study. Tim ini dilakukan oleh dosen (peneliti) dalam menyusun pelaksanaan pembelajaran (materi, media, metode, dan strategi) bersama beberapa guru kelas agar kualitas pembelajaran lebih optimal dan dirancang sesuai dengan karakteristik dan kebutuhan siswa. Lesson study merupakan perencanaan yang terdiri dari model, strategi, pendekatan, metode dan teknik yang efektif dilaksanakan di kelas dalam proses pembelajaran yang sesuai dengan 
karakteristik dan lingkungan belajar siswa. Sedangkan menurut Nuryanto (2016: 44) lesson study yaitu serangkaian kegiatan pembelajaran yang dapat diterapkan yang terdiri dari berbagai metode dan strategi pembelajaran yang dianggap efektif dan sesuai dengan situasi, kondisi, dan permasalahan yang faktual yang dihadapi guru di dalam kelas.

SDN 2 Pringapus merupakan sekolah yang berlokasi jauh dari perkotaan sehingga dalam mengakses ilmu baru mengalami kendala dari segi sarana dan prasarana. Sekolah ini sudah mulai menerapkan Kurikulum 2013, namun mengalami beberapa permasalahan yaitu: (1) sumber daya manusia (guru) belum memiliki kemampuan dan pengetahuan terkait merancang pembelajaran yang yang sesuai dengan Kurikulum 2013, (2) sudah ada pelatihan khusus, namun dalam implementasinya guru masih kesulitan, (3) kurang adanya fasilitas dalam mencari media, model, metode, strategi pembelajaran dan (4) masih menggunakan metode ceramah (Teacher Centered Learning) sehingga dibutuhkan pembelajaran yang berpusat pada siswa (Student Centered Learning).

Uraian di atas memperlihatkan bahwa diperlukan pembelajaran yang berpusat pada siswa untuk menunjang pembelajaran langsung, memperkuat pendekatan ilmiah (scientific), tematik terpadu (tematik antarmata pelajaran), dan tematik (dalam suatu mata pelajaran) perlu diterapkan pembelajaran berbasis penyingkapan/penelitian

(discovery/inquiry learning) (Azzahro, 2014: 1). Discovery learning merupakan metode pembelajaran yang mengedepankan proses pembelajaran yang di dalamnya terdapat pengembangan perpikir siswa dalam memecahkan masalah sehari-hari yang ditekankan pada kemampuan siswa dalam mencari ide-ide baru. Menurut Fitri (2015: 91) Discovery Learning merupakan sebuah model pengajaran yang dirancang dengan tujuan untuk membantu siswa mengembangkan kemampuan berfikir dan mengembangkan kemampuan dalam memecahkan masalah kehidupan sehari-hari, yang menekankan pada pentingnya membantu siswa untuk memahami struktur atau ide-ide kunci suatu disiplin ilmu, kebutuhan akan keterlibatan aktif siswa dalam proses belajar, dan keyakinan bahwa pembelajaran sejati terjadi melalui penemuan pribadi. mengembangkan kemampuan dalam memecahkan masalah kehidupan seharihari.

Sedangkan menurut Rozhana (2017: 199)

Problem Based Instruction yaitu melibatkan siswa pada setiap kegiatan pembelajaran sehingga pengetahuan diserap dengan baik dan melatih siswa untuk bekerjasama dengan siswa lainnya. Melalui pembentukan tim lesson study (plan, do, see) guru/model/observer mampu mengaktifkan siswa melalui metode pembelajaran Discovery Learning dan Problem Based Instruction.

\section{METODE PENELITIAN}

Metode penelitian ini menggunakan metode deskripstif kualitatif dengan data yang dikumpulkan melalui observasi, wawancara, dokumentasi, dan analisis deskriptif kualitatif (Moleong, dalam Rozhana, 2018). Laporan penelitian hasil riset berupa kutipan-kutipan data yang diperoleh selama observasi untuk memberikan gambaran penyajian laporan. 
Penelitian ini dilaksanakan di SDN 2 Pringapus Kecamatan Dongko Kabupaten Trenggalek yang beralamatkan di RT 39 RW 08 Desa Pringapus Dusun Picis. Kelas yang dijadikan binaan yaitu kelas $\mathrm{V}$ dengan jumlah siswa 15. Penerapan penelitian dirancang sesuai dengan Lesson Study yang terdiri dari tiga tahap yaitu:

a) Perencanaan (Plan)

Pada tahap ini pembelajaran berfokus pada ranah kognitif atau pengetahuan yang rendah. Contohnya mengetahui dan memahami. Rumusan tahapan ini tertuang dalam RPP yang berakibat alokasi waktu belajar terbatas di sekolah dan lebih banyak mengenalkan dan mempelajari hal-hal yang bersifat kognitif faktual atau paling tinggi konseptual dan prosedural belum sampai pada pengetahuan dan keterampilan metakognitif. Pada level metakognitif, seharusnya siswa telah mampu menggunakan pengetahuan dan pemahamannya untuk menganalisis dan merefleksi pengalaman belajarnya, termasuk mengatasi dan memecahkan kesulitannya, sehingga siswa akan berkembang menjadi pembelajar mandiri (self regulated learner). Yang harus dirumuskan dalam tahap perencanaan (Plan) yaitu: (1) Chapter Design yang di dalammnya terdapat tujuan untuk memetakan pemahaman pada tiap bab dan mengkonkritkan materi dengan cara membahas sebenarnya esensi yang akan diberikan; prinsip yaitu membuat mind mapping dan mindset ketika membuat chapter design adalah guru/dosen, fokus pada pengembangan materi, dan menganalisis materi esensial dan materi non esensial; dan tahapan yang teridiri memilih dan menuliskan tema pembelajaran atau judul bab, pikirkan hal-hal penting apa yang perlu dikuasai siswa sebelum dan sesudah belajar bab ini, buat cabang satu persatu untuk setiap konsep penting dan terus bahas sampai pada esensi konsepnya, setiap cabang dan anak cabang sebisanya hanya menggunakan 1 (satu) kata kunci saja, pikirkan hubungan antara satu konsep dengan konsep lainnya di dalam bab, pertimbangkan urutan belajar yang paling mudah untuk siswa dan alokasi pertemuan untuk bab tersebut, pilih materi yang mana yang akan digunakan untuk open-class. (2) Analisis materi yaitu memilih materi esensial dan non esensial dan merenungkan dan merefleksi kembali konsep-konsep utama, prosedur dan keterampilan penting, serta pengalaman pembelajaran sebelumnya, baik pada jenjang pendidikan di bawah atau di atasnya (3) Lesson design yaitu mengarahkan kemampuan berpikir siswa secara kritis, analitis, kreatif, dan metakognitif. Serta, mengembangkan sikap dan keterampilan. Menurut Nuryanto (2016, 2016: 6) pada tahap perencanaan dilakukan identifikasi masalah kelas dan menentukan alternatif pemecahan masalah yang berkaitan dengan pokok bahasan yang relevan dengan kelas dan jadwal pelajaran, karakteristik siswa, dan suasana kelas, metode dan pendekatan pembelajaran, media, alat peraga, dan evaluasi proses hasil belajar. Dari hasil tersebut didiskusikan (dalam kelompok LS) dan diterapkan oleh guru (model)

b) Pelaksanaan dan Observasi (Do)

Pada tahap pelaksanaan seorang guru (model) melakukan implementasi RPP yang telah disusun di tahap Plan. Guru lain bertugas sebagai observer dengan menggunakan lembar yang telah 
disiapkan (Subadi, 2013: 24). Dalam tahap pelaksaan dan observasi ada beberapa hal yang perlu diperhatikan yaitu pemahaman dan keberanian mengeksekusi setiap tahapan belajar sesuai dengan kemampuan guru, meyediakan semua alat, bahan, dan media yang dibutuhkan, mengawali kegiatan belajar dengan salam dan senyum, perhatian guru berpusat ke semua siswa di kelas, dan mengatur manajemen waktu serta cara berkomunikasi yang baik dan sesuai. Sedangkan ada beberapa hal yang perlu diperhatikan oleh seorang observer yaitu masuk kelas tepat waktu, posisi observer yang tidak mengganggu siswa saat belajar, membawa lembar kosong untuk mencatat, fokus mengamati aktivitas belajar dan siswa yang dianggap menarik untuk diamati, catat hal-hal yang penting untuk dibahas pada kegiatan refleksi, dan melakukan wawancara kepada beberapa siswa. Sedangkan menurut Winarsih (2012: 45) yaitu Tim LS melaksanakan kegiatan analisis materi, silabus, model pembelajaran dan pendekatan yang akan digunakan dalam proses pembelajaran, serta menentukan guru model dan lokasi yang digunakan untuk penelitian.

\section{c) Refleksi (See)}

Dalam tahap refleksi terdiri dari 4 level yang perlu diperhatikan oleh tim lesson study sebagai berikut: (1) Level 1 yaitu komentar mengarah kepada aktivitas mengajar guru secara persial, tidak fokus siswa dalam belajar, tanpa saran dan mengupas kesalahan guru, (2) Level 2 yaitu komentar mengarah kepada aktivitas siswa secara persial, fokus dapa aktivitas siswa, adanya saran, dan laporan pandangan mata persial, (3) Level 3 yaitu fokus pada aktivitas dan konsep siswa, solusi masih persial, cenderung pada apa yang seharusnya pembelajaran lakukan, dan (4) Level 4 yaitu fokus pada cara konsep diajarkan untuk mencapai tujuan pembelajaran, desain alternative (pembelajaran sama untuk waktu lainnya), dan mengupayakan cara berpikir siswa terbentuk lebih baik.

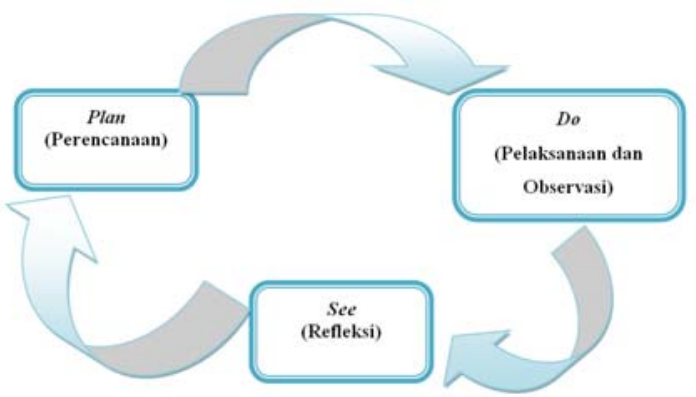

Gambar 1.1 Tahap Lesson Study.........Siklus 1 dst Data yang dikumpulkan dalam Penelitian Tindakan Kelas ini tentang proses pembelajaran, termasuk interaksi guru-siswa dan siswa-siswa yang relevan, sebelum dan sesudah dilakukan tindakan dan data mengenai hasil belajar siswa. Sumber data yang utama dalam penelitian ini yaitu siswa kelas V SDN 2 Pringapus Kabupaten Trenggalek, karena merekalah yang akan menampilkan perubahan yang terjadi akibat penerapan tindakan. Dalam tabel 1.1 dapat dilihat data, sumber data, intrumen dan proses pengambilan data.

Tablel 1.1 Data, Sumber Data dan Instrumen Penelitian

\begin{tabular}{|c|c|c|c|}
\hline Data & $\begin{array}{c}\text { Sumber } \\
\text { Data }\end{array}$ & Instrumen & Proses \\
\hline $\begin{array}{l}\text { Proses } \\
\text { pembel } \\
\text { ajaran }\end{array}$ & Siswa & $\begin{array}{l}\text { Angket } \\
\text { Observasi }\end{array}$ & $\begin{array}{l}\text { Melihat } \\
\text { aktivitas siswa } \\
\text { dalam belajar }\end{array}$ \\
\hline
\end{tabular}

Peneliti menggunakan beberapa teknik pengumpulan data untuk memperoleh informasi berupa observasi, wawancara, dan dokumentasi. Untuk menganalisa data dalam penelitian ini digunakan teknik analisa data kualitatif 
deskriptif yang berupa informasi berbentuk kalimat.

\section{HASIL DAN PEMBAHASAN}

Berdasarkan penelitian yang dilakukan bersama oleh peneliti selama implementasi lesson study di SDN 2 Pringapus dengan menerapkan model pembelajaran Discovery Learning dan Problem Based Instruction berjalan dengan baik. Langkah pertama pada proses lesson study yaitu plan (perencanaan) perancanaan ini dimulai dengan menetapkan materi yang akan di ajarkan, menyusun RPP, membentuk tim lesson study. Pada saat perencanaan guru model bersama tim lesson study menyepakati bersama proses pmeblajaran di kelas yang nantinya diterapkan. Selain RPP juga menggunakan media pembelajaran harapannya untuk siswa aktif saat pembelajaran di kelas. Tim sepakat mengambil tema 1 "organ gerak hewan dan manusia” subtema 1 "organ gera hewan” pembelajaran 1. Serta menyiapkan media pembelajaran berupa video pembelajaran. Dalam perencanaan terdapat beberapa perdebatan antara guru model dan observer karena mengingat di SD tersebut masih kekurangan fasilitas yang memadai. Sehingga penayangan media menggunakan leptop bukan LCD. Dalam merancang pembelajaran tim telah menyesuaikan dengan karakteristik anak.

Selanjutnya tahap do (pelaksanaan) yang terdiri dari satu guru model dan empat observer yang mengobservasi jalannya pembelajaran. Dalam proses ini pelaksanaan pembelajaran dimulai dari datangnya tim observer dan guru model ke ruang gelas, saat itu siswa terlihat kaget karena banyak guru yang masuk ke dalam kelas. Guru model memberikan salam dan dijawab serentak oleh siswa kelas V. Guru model mengajak siswa berdoa terlebih dahulu sebelum memulai pembelajaran. Kemudian, guru model menjelaskan kepada siswa bahwa dalam proses pembelajaran dilaksanakan dengan para guru lainnya serta melihat proses pembelajaran. Guru menyampaikan materi dan terlihat beberapa siswa antusias dengan proses pembelajaran karena biasanya guru menggunakan metode ceramah dan saat itu guru menggunakan model pembelajaran sehingga membangkitkan motivasi belajar siswa. Dalam proses pelaksanaan ditemukan beberapa temuan yang nampak dari aktivitas siswa yaitu (1) terdapat 5 siswa yang canggung dengan suasana pelajaran, dikarenakan terdapat beberapa guru yang masuk ke dalam kelas, guru model mencoba mencairkan suasana dengan bernyanyi dan yel-yel sehingga tidak merasa ada guru lain yang ada dikelas, (2) pada saat pemberian tugas dan terlihat siswa tidak bisa menjawab, siswa tersebut bertanya kepada salah satu observer, (3) siswa aktif dalam bertanya jawab saat penggunaan model pembelajaran yang biasanya hanya diam ternyata dengan model pembelajaran Discovery Learning dan Problem Based Instruction perperan serta dalam diskusi, dan (4) interaksi antar siswa dan siswa, siswa dan guru, guru dan siswa melalui metode Discovery Learning dan Problem Based Instruction dapat dinayatakana berhasil. Setelah pelaksanaan di kelas guru melanjutkan ke tahap see (refleksi).

Tahap refleksi yaitu tahap dimana tim observer dan guru model menindaklanjuti kegiatan Lesson Study yang telah terlaksana. Kegiatan diawali dengan mengutarakan kesan dari proses pembelajaran dan dilanjutkan pada pengamatan selama observasi kelas Lesson Study. Tim observer memberikan kritik dan saran terkait proses pembelajaran di kelas. Saran dan masukan positif sangat penting untuk merancang proses pembelajaran agar lebih baik kedepannya. Selama proses pembelajaran terlihat bahwa aktivitas siswa bagus, namun terdapat beberapa siswa yang 
masih kurang aktif. Hal ini bisa terjadi karena siswa tersebut tidak tebiasa saat ada guru/tim observer masuk ke dalam kelas. Selama pembelajaran siswa aktif dan metode Discovery Learning dan Problem Based Instruction sangat layak diterapkan dalam proses pembelajaran. Saran lain yaitu kurangnya media pembelajaran sehingga aktualisasi materi masih kurang, dan dalam proses pembelajaran ini seharusnya terus dilaksanakan untuk memperbaiki kualitas guru dalam mengajar serta meningkatkan aktivitas siswa dalam belajar di kelas.

\section{SIMPULAN}

Tahap dalam membentuk tim lesson study terdapat tiga tahapan yaitu Plan (Perencanaan) membentuk tim lessn studi yang terdiri dari beberapa guru kelas untuk merencanakan rencana pelaksanaan pembelajaran (RPP) yang terdiri dari media, model, metode, strategi yang kiranya akan diterapkan dalam proses mengajar. Dalam tahap ini tim mengupas materi bersama yang akan di ajarkan dan nantinya akan di observer bersama. Do (Pelaksanaan dan Observasi) yaitu melaksanakan hasil dari perencanaan dan di tuangkan dalam proses pembelajaran dikelas. Observer bertugas melihat/mengamati hal-hal yang dirasa menarik atau siswa yang dianggap menarik. Tahap terakhir yaitu See (Refleksi) pada tahap ini guru (model) dan observer membahas bersama kelemahan apa yang ada saat pelaksanaan pembelajaran. Setelah dilakukan siklus 1, tahap selanjutnya yaitu memulai siklus 2 dengan tahapan plan, do, see dapat menggunakan metode lainnya.

\section{DAFTAR PUSTAKA}

Akbar, Sa'dun. 2010. Peneletian Tindakan Kelas. Yogyakarta: Cipta Media Aksara.

Azzahro, Fatimah. 2014. Pengembangan Perangkat Pembelajaran Berbasis Discovery Learning pada Sub Materi Respirasi dan Fotosintesis Kelas VII SMP. Jurnal Pemdidikan Sains Unesa, Vol 2 No 03 (http://jurnalmahasiswa.unesa.ac.id/i ndex.php/pensa/article/view/9390) diakses 15 Mei 2019.

Fitri, M \& Derlina. 2015. Pengaruh Model Pembelajaran Discovery Learning Terhadap Hasil Belajar Siswa pada Materi Pokok Suhu dan Kalor. Jurnal INPAFI (Inovasi Pembelajaran Fisika), Vol 3 No 2 (2015) (online) http://jurnal.unimed.ac.id/2012/index .php/inpafi/article/view/5130/8113 diakses 15 Mei 2019.

Nuryanto. 2016. Pendekatan Scientific Berbasis Lesson Study Dalam Pembelajaran Tematik Terpadu Konteks Peningkatan Professional Guru. Jurnal Elementary, Vol 2 Edisi 3 Januari $2016 \quad$ (online) (http://download.portalgaruda.org/art icle.php?article $=496234 \&$ val $=10158$ \&title $=\% 20$ PENDEKATAN\%20SCI ENTIFIC\%20BERBASIS\%20LESS ON\%20STUDY\%20DALAM\%20P EMBELAJARAN\%20TEMATIK\% 20TERPADU\%20KONTEKS\%20P ENINGKATAN\%20PROFESIONA LITAS\%20GURU), di askes $16 \mathrm{Mei}$ 2019. 
Rozhana, K,M \& Fidiastuti, H, R. 2017. Model Problem Based Intruction Berbantu Mind Mapping pada Materi Permasalahan Sosial di Lingkungan Setempat untuk Meningkatkan Aktivitas dan Hasil Belajar Siswa Kelas IV SD. Jurnal Pendidikan Dasar Nusantara, Volume 2 Nomor $22017 \quad$ (online) (http://ojs.unpkediri.ac.id/index.php/ pgsd/article/view/553/421), diakses 15 Mei 2019.

Rozhana, K,M \& Sari, N,K. 2018. Pelaksanaan Pendidikan Karakter dalam Proses Pembelajaran untuk Menumbuhkan Sikap Nasionalisme. Prosiding Seminar Nasional Pengembangan Profesionalisme Dosen dan Guru Indonesia, Volume 2 (Online)

(https://semnas.unikama.ac.id/fip/un duhan/2018/47851298.pdf), di akses 21 Juni 2019.
Sari, NK. 2016. Kemampuan Berpikir Kreatif Konsep Geometri Siswa. Prosiding Seminar Nasional Pendidikan Matematika. Volume 1 (online)

http://repository.unikama.ac.id/839/1 /PROSIDING\%20SEMINAR\%20N ASIONAL\%20PENDIDIKAN\%20 MATEMATIKA\%202016.pdf, diakses 15 Mei 2019.

Subadi, Tjipto. 2013. Lesson Study sebagai Inovasi Pendidikan. Surakarta: Kafilah Publishing.

Winarsih, A \& Mulyani, S. 2012. Peningkatan Profesionalisme Guru Ipa Melalui Lesson Study dalam Pengembangan Model Pembelajaran PBI. Jurnal Pendidikan IPA Indonesia, 1(1) (2014) 43-50 (online) https://journal.unnes.ac.id/nju/index. php/jpii/article/view/2012/2126 diakses 16 Mei 2019. 